metabolites might act both by changing viscoelastic properties of the mucin (thus facilitating penetration?) and by causing tissue injuries, and thus paving the way for peptic ulcer disease.

This work was partly supported by the Research Committee of Örebro County Council and the Örebro Medical Center Research Foundation. We thank $M$ Jurstrand and $A$ Mörttinen for their excellent technical help.

This work was presented in part at the VI European Workshop on Gastroduodenal Pathology and Helicobacter pylori (Acta Gastroenterologica Belgica 1993;56 (Suppl):119 (Abstract))

1 Marshall BJ, Armstrong JA, McGechie DB, Glancy RJ. Attempt to fulfill Koch's postulates for pyloric campylobacter. Med F Aust 1985;142:436-43.

2 Morris A, Nicholson G. Ingestion of Campylobacter pyloridis causes gastritis and raised fasting gastric $\mathrm{pH}$. Am 7 Gastroenterol 1987;82:192-9.

3 Rauws EAJ, Tytgat GNJ. Cure of duodenal ulcer associ- ated with eradication of Helicobacter pylori. Lancet $1990 ; 335: 1233-5$

4 Rautelin H, Blomberg B, Fredlund H, Järnerot G, Danielsson D. Incidence of Helicobacter pylori strains activating neutrophils in patients with peptic ulcer disease. Gut 1993;34:599-603.

5 Kosunen TU, Höök J, Rautelin HI, Myllylä G. Agedependent increase of Campylobacter pylori antibodies in blood donors. Scand $\mathcal{F}$ Gastroenterol 1989;24:110-4.

6 Fredlund H, Olcen P, Danielsson D. A reference procedure to study chemiluminescence induced in polymorphonuclear leukocytes by Neisseria meningitidis. phonuclear leukocytes

7 High N, Mounier J, Prévost MC, Sansonetti PJ. IpaB of Shigella flexneri causes entry into epithelial cells and Shigella flexneri causes entry into epithelial cells and escape f

8 Bernatowska E, Jose P, Davies H, Stephenson M, Webster D. Interaction of Campylobacter species with antibody, complement and phagocytes. Gut 1989;30:906-11.

9 Andersen LP, Blom J, Nielsen $H$. Survival and ultrastructural changes of Helicobacter pylori after phagocytosis by human polymorphonuclear leukocytes and monocytes. APMIS 1993;101:61-72.

10 Grisham MB, von Ritter C, Smith BF, Lamont JT, Granger DN. Interaction between oxygen radicals and gastrin mucin. Am f Physiol 1987;253:G93-6.

\title{
IgD multiple myeloma with thoracic spine compression due to epidural extra-osseous tumour spread
}

\author{
Y I Lolin, C W Lam, W H Lo, K L Au, J R L Masarei
}

\begin{abstract}
On initial presentation of a patient with IgD multiple myeloma there were no features to suggest an unusual variant. Two months later she developed spinal cord compression due to an IgD plasmacytoma. This complication of IgD myeloma has rarely been reported. During the course of the disease and using the routine laboratory protocol for investigating and identifying paraproteins, including IgD, the patient's results became indistinguishable from those in Bence-Jones proteinuria myeloma.
\end{abstract}

\section{$(\mathcal{F}$ Clin Pathol 1994;47:669-671)}

Department of

Chemical Pathology,

Prince of Wales

Hospital, Chinese

University of Hong

Kong, Shatin, NT,

Hong Kong

Y I Lolin

J R L Masarei

Department of

Pathology, Princess

Margaret Hospital,

Princess Margaret

Road, Lai Chi Kok,

Hong Kong

C W Lam

W H Lo

$\mathrm{K} \mathrm{L} \mathrm{Au}$

Correspondence to:

Dr Y I Lolin

Accepted for publication

11 January 1994
IgD myeloma is rare. ${ }^{1-4}$ It generally follows a shorter course than other forms of myeloma, with more frequent extra-osseous spread, renal insufficiency, Bence-Jones proteinuria and atypical presentations and complications. ${ }^{1-3}$ The paraprotein band is also often either not visible or faint and diffuse. ${ }^{145}$ This, in conjunction with the usual large excess of Bence-Jones protein in the urine, can lead to a misdiagnosis of a Bence-Jones proteinuria myeloma. ${ }^{6}$

We report, as far as we are aware, the first documented case of IgD multiple myeloma in a Hong Kong Chinese patient. Although initially there were no distinctive features to suggest a rarer myeloma, she later developed thoracic spinal cord compression due to a soft tissue plasmacytoma. This particular complication is rare with IgD myelomas: our case seems to be only the second one described in the English language. ${ }^{7}$

\section{Case report}

A 55 year old Chinese woman presented with spontaneous low back pain. She had also had an episode of back pain one month earlier after a fall. Physical examination showed that she was pale, with muscle spasm over the lower back and local tenderness over the L5 vertebra, but was otherwise unremarkable. Investigations showed a haemoglobin of 103 $\mathrm{g} / \mathrm{l}$, normochromic normocytic anaemia, an erythrocyte sedimentation rate of $60 \mathrm{~mm} /$ first hour, white cells of $5 \times 10^{9} / 1$ (with a normal differential count) and a platelet count of $171 \times 10^{9} / 1$. The serum renal and liver function tests all yielded normal results. Serum total protein was $75 \mathrm{~g} / \mathrm{l}$, albumin $52 \mathrm{~g} / \mathrm{l}$, and the albumin adjusted calcium $2.33 \mathrm{mmol} / 1 . X$ ray pictures of the lumbar spine showed a collapsed L5 vertebra. Skull $x$ ray pictures showed multiple osteolytic lesions and a trephine bone marrow biopsy specimen of the iliac crest showed $95 \%$ plasma cells. The serum IgA was $0.5 \mathrm{~g} / 1$ (range $1 \cdot 25-4 \cdot 26$ ), IgG $7 \cdot 18 \mathrm{~g} / 1$ (range $7 \cdot 90-17 \cdot 90$ ), and $\operatorname{IgM} 0 \cdot 27 \mathrm{~g} / 1$ (range $0.63-3.07 \mathrm{~g} / \mathrm{l}$ ). Serum protein electrophoresis (agarose gels; Beckman Paragon SPE kit) showed a small, discrete paraprotein band of $4 \mathrm{~g} / 1$ in the mid $\beta / \gamma$ region (figure). Urine contained $0.9 \mathrm{~g} / 1$ of protein and a faint 
albumin and a large paraprotein band on electrophoresis. Bence-Jones proteinuria myeloma was suspected and the patient was started on a course of chemotherapy with melphalan, prednisone, and allopurinol. However, routine serum immunofixation with $\operatorname{IgG}, \operatorname{Ig} A, \operatorname{Ig} M$, and bound and free $\kappa$ and $\lambda$ light chain antisera (Beckman Paragon immunofixation kit) revealed two small monoclonal bands, both reacting with the bound and free $\lambda$ light chain antiserum only, one in the same position as the band on serum protein electrophoresis and one faster (figure). Subsequent immunofixation with free-only $\lambda$ light chain ( $f \lambda$ ) antiserum (Daco Products) identified the faster band as a $\lambda$ Bence-Jones protein. Further immunofixation with IgD and IgE antisera (Daco Products) identified the band in the mid $\beta / \gamma$ region as an IgD paraprotein (figure).

Two months later, while she was receiving the second course of chemotherapy, the patient was re-admitted because of acute spinal cord compression. Magnetic resonance imaging confirmed an epidural mass at the level of T4/5 and intact bone structure. Spinal cord decompression by hemilaminectomy at T4/5 was done, together with debulking of the tumour. On histological examination the tumour was identical with that in the bone marrow, and on immunohistochemical and immunofluorescence staining the plasma cells contained excess IgD and $\lambda$ chains. Repeat serum protein electrophoresis showed no band in the mid- $\beta / \gamma$ region, but an extremely faint faster band. Routine immunofixation showed that only this band was detected with the bound and free light chain antiserum and identified with $\mathrm{f} \lambda$ antiserum as $\lambda$ Bence-Jones protein. However, immunofixation with IgD antiserum showed an additional, albeit very faint, band in the mid $\beta / \gamma$ region. Total IgD and $\beta_{2}$-microglobulin were $580 \mathrm{IgD}$ units $/ \mathrm{ml}$ (normal <20) and $1.9 \mu \mathrm{g} / \mathrm{ml}$ (normal <2), respectively. The results of urine protein studies were as before.

The postoperative recovery was complicated by Pseudomonas aeruginosa urinary tract infection. Sensation and power improved initially, but the tumour did not respond to treatment. The patient became increasingly pancytopenic. Renal function tests remained normal until two weeks before death when she

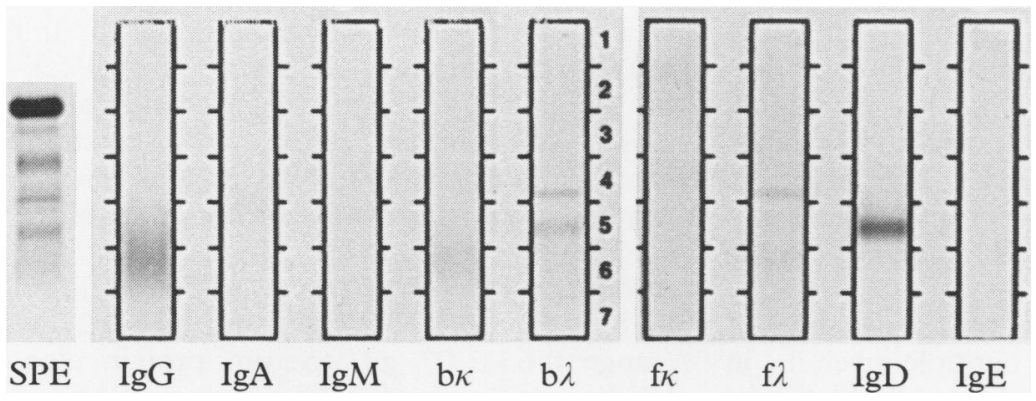

Serum protein electrophoretic pattern (SPE) and results of immunofixation with IgG, IgA, $I g M$, bound and free $\kappa(b \kappa)$, bound and free $\lambda(b \lambda)$, free-only $\kappa(f \kappa)$, free-only $\lambda(f \lambda)$, $\operatorname{Ig} D$ and IgE antisera in the first serum received. The patterns on the later sera are not shown because the bands were very faint. started to become increasingly uraemic, acidotic, and hypocalcaemic. The total serum IgD and $\beta_{2}$-microglobulin concentrations one week before death were $458 \mathrm{IgD}$ units $/ \mathrm{ml}$ and $0.5 \mu \mathrm{l} / \mathrm{ml}$, respectively. The serum protein electrophoresis was similar to that described in the second sample above, but immunosuppression was more noticeable. The urine (total protein $0.9 \mathrm{~g} / \mathrm{l}$ ) protein studies remained as before. Immunofixation was not carried out. The patient died from renal failure and septicaemic shock seven months after admission.

\section{Discussion}

IgD myeloma is rare, and even the suggested incidence of $1 \%$ to $3 \%$ of all cases of myeloma ${ }^{12}$ may be an overestimate. ${ }^{2}$ It differs from the more common types in a number of features. It tends to occur in younger patients with a preponderance in men. ${ }^{13}$ Extra-osseous spread and soft tissue tumours are common. ${ }^{1-38}$ More than $50 \%$ of patients have lymphadenopathy, splenomegaly, and hepatomegaly. ${ }^{13}$ Renal impairment and Bence-Jones proteinuria occur in at least $90 \%$ of patients, ${ }^{12}$ with one series showing $55 \%$ of patients being initially investigated for the cause of renal failure. ${ }^{8}$ Plasma cell leukaemia occurs in up to $14 \%^{13}$ and amyloidosis in up to $44 \% .^{1}$ Survival seems to be shorter than with other types of myeloma, with $60 \%$ of patients dying within 12 months of diagnosis. $^{1-4}$

At presentation our patient had no clinical, radiological, and histological features to suggest a rare type of myeloma, such as no obvious extra-osseous spread, organ enlargement, or renal failure. Later on, however, despite chemotherapy, she developed thoracic spine cord compression through extra-osseous tumour spread. Although a number of unusual sites for IgD myeloma extra-osseous spread have been reported, such as lung, muscle, and pancreas, ${ }^{126-8}$ an epidural soft tissue tumour is rare. To our knowledge this is only the second such case reported in the English language. ${ }^{7}$ Spinal cord compression due to extra-osseous spread, with and without local spinal bone pathology, occurs in about $5 \%$ of all cases of myeloma. ${ }^{7}$ Another feature in our patient was that the $\beta_{2}$-microglobulin concentrations, renal function, calcium values, follow up paraprotein studies and IgD quantitations did not correlate with tumour spread and prognosis. Although these are useful prognostic factors for other myelomas ${ }^{39}$ they may not be applicable in patients with IgD myeloma. Similar observations have also been noted by others. ${ }^{134}$

Most IgD myelomas secrete excess $\lambda$ light chains. ${ }^{1-48}$ The quantity of paraprotein is generally much lower than with the commoner myelomas and is often not detectable on routine serum protein electrophoresis. ${ }^{14-10}$ As immunosuppression, Bence-Jones proteinuria and often Bence-Jones proteinaemia are usually present, ${ }^{1-3}$ a misdiagnosis of the commoner Bence-Jones proteinuria myeloma, 
especially if the IgD band is not visible and a rare myeloma variant is not suspected, can easily be made. ${ }^{26}$ In one case with no obvious serum paraprotein IgD paraproteinaemia was detected by immunoelectrophoresis seven months after myeloma had been diagnosed and treatment started. ${ }^{10}$ IgD paraprotein concentrations of up to $31 \mathrm{~g} / 1$ have, however, also been seen. ${ }^{5}$

In our laboratory the investigation of paraproteins is based on recommended procedures. ${ }^{9}$ Immunofixation of serum is carried out routinely with $\operatorname{IgG}, \operatorname{IgA}, \operatorname{IgM}$ and bound and free $\kappa$ and $\lambda$ chain antisera. If an immunofixation pattern is obtained only with the bound and free light chain antiserum, serum is further immunofixed with free-only light chain antisera and, if the band still cannot be identified, with IgD and IgE antisera. For urine, the immunofixation policy is to look only for the heavy chain already identified in blood and for Bence-Jones proteinuria. Although in our patient the initial serum and urine protein studies suggested Bence-Jones proteinuria myeloma because of the faint band in serum, immunosuppression, and a prominent band in urine, the protocol for paraprotein studies led us to the correct diagnosis and to subsequent relevant histochemical staining of the soft tissue tumour and IgD immunoglobulin quantitation. However, on repeating the protein studies on fresh samples six weeks later, to obtain a more representative immunofixation pattern for a photographic record, the paraprotein band in serum was barely visible and there was nothing on the serum protein electrophoresis and immunofixation patterns to suggest that immunofixation with $\operatorname{IgD}$ antiserum should follow. It is doubtful whether we would have carried it out were this to have been the first serum sample received. This raises the question whether, as suggested by some, ${ }^{6}$ one should routinely immunofix with $\operatorname{IgD}$ and $\operatorname{IgE}$ antisera sera from all patients with a suspected Bence-Jones proteinuria myeloma, irrespective of whether a suspicious band is detected on serum protein electrophoresis or after immunofixation with light chains.

We are indebted to Dr Eric Chan, Immunology Department, Queen Mary Hospital, for assaying the serum $\beta_{2^{-}}$ microglobulin and IgD, to $\mathrm{Mr} \mathrm{HT}$ Au for preparation of photomicrographs, and to Ms Begonia Yuen for typing the manuscript.

1 Jancelowicz Z, Takatsuki K, Sugai S, Pruzanski W. IgD multiple myeloma. A review of 133 cases. Arch Intern Med 1975;135:87-93.

2 Hobbs JR, Corbett AA. Younger age of presentation and extraosseous tumour in IgD myelomatosis. $B M$ 1969;i:412-4.

3 Shimamoto $Y$, Anami Y, Yamaguchi M. A new risk grouping for IgD myeloma based on analysis of 165 Japanese ing for IgD myeloma based on analysis of

4 Le Quellec A, Bataille R, Levy-Robinet M, Sany J, Ce Quellec A, Bataille R, Levy-Robinet M, Sany J,
Ciurana AJ. Immunoglobulin D multiple myeloma. A retrospective study in the Languedoc region. Presse-Med 1989;18:1110-3.

5 Maccallum PK, Freemont AJ, Geary CG, Liu Yin JA. A case of IgD myeloma presenting as diffuse osteosclerosis. $f$ Clin Pathol 1988;41:486-9.

6 Ozaki M, Yamanaka H. A case of IgD myeloma with extraosseous spread to the gingiva. Oral Surg Oral Med Oral Pathol 1988;65:726-30.

7 Matsui H, Fujie H, Tsuji H. Extraosseous epidural tumor of immunoglobulin D myeloma. F Spinal Disord 1992; 5:366-9.

8 Bergesio F, Salvadori M, Lombardi M, Michelassi S Salerno A, Monzani G, et al. Renal involvement in IgD myeloma. Scand f Urol Nephrol 1988;22:309-12.

myeloma. Scand F Urol Nephrol 1988;22:309-12.
9 Riches PG, Hobbs JR. Laboratory investigation of paraproteinaemia. Broadsheet 188. F Clin Pathol 1988, 41:776-85.

10 Kyle RA. IgD multiple myeloma: a cure at 21 years. $A m \mathcal{f}$ Hematol 1988;29:41-3. 